\title{
Medical genetics in developing countries in the Asia-Pacific region: challenges and opportunities
}

\author{
Meow-Keong Thong, MD ${ }^{1}$, Yiling See-Toh, MBBS ${ }^{1}$, Jamiyah Hassan, MMed(O\&G) ${ }^{2}$ and Jaffar Ali, PhD ${ }^{3}$
}

\begin{abstract}
Advances in genetic and genomic technology changed health-care services rapidly in low and middle income countries (LMICs) in the Asia-Pacific region. While genetic services were initially focused on population-based disease prevention strategies, they have evolved into clinic-based and therapeutics-oriented service. Many LMICs struggled with these noncommunicable diseases and were unprepared for the needs of a clinical genetic service. The emergence of a middle class population, the lack of regulatory oversight, and weak capacity-building in medical genetics expertise and genetic counseling services led to a range of genetic services of variable quality with minimal ethical oversight. Some of the current shortcomings faced include the lack of awareness of cultural values in genetic health care, the variable stages of socioeconomic development and educational background that led to increased demand and abuse of genetics, the role of women in society and the
\end{abstract}

crisis of gender selection, the lack of preventive and care services for genetic and birth defects, the issues of gene ethics in medicine, and the lack of understanding of some religious controversies. These challenges provide opportunities for both developing and developed nations to work together to reduce the inequalities and to ensure a caring, inclusive, ethical, and cost-effective genetic service in the region.

Genetics in Medicine (2018) 20:1114-1121; https://doi.org/10.1038/ s41436-018-0135-0

Keywords: medical genetics services; developing countries; AsiaPacific; challenges; opportunities

\section{INTRODUCTION}

Advances in genetic and genomic technology have accelerated the introduction of genetic services into the health-care delivery system in the Asia-Pacific region. As elsewhere in the world, genetic services initially used population-based disease prevention strategies. In the past two decades, as health indices and the socioeconomic status of the Asia-Pacific region improved, genetic service became increasingly clinicbased and therapeutics-oriented. Many health-care systems in the region were unprepared for the needs of a clinical genetic service and have struggled to cope with both communicable and noncommunicable diseases. In addition, the combination of demands from a large emerging middle class population and the lack of regulatory oversight and capacity-building in medical genetics expertise and genetic counseling services have led to a range of genetic services of variable quality with minimal ethical oversight and legal provisions. ${ }^{1-3}$

Developing necessary genetic services is impaired by the lack of accurate data on genetic conditions and inherited disorders because there are few dedicated birth defect registries or rare diseases registries in this region. ${ }^{4}$ The pattern and types of genetic diseases in developing countries are quite variable, even within the same geographic region. Physicians and clinical geneticists trained in developed countries may encounter genetic diseases in the local population in their respective countries that they may be unfamiliar with, but which are common diseases in the region, such as citrin deficiency, Barts hydrops, and distal renal tubular acidosis-Southeast Asian ovalocytosis syndromes. Syndromic genetic conditions characterized by subtle physical differences may be particularly challenging if the clinician receives their training in a country with a different ethnic population. While these are issues being addressed in all countries providing genetic services, we will highlight issues specific to Asian countries.

\section{Cultural and socioeconomic perspectives in medical genetics}

In developing countries, most genetic services began in the last decade of the twentieth century, usually from academic institutions such as universities and research institutions. ${ }^{1}$ These services are usually led by pediatricians who specialized in medical or clinical genetics. The preponderance of pediatricians, like elsewhere in the world, is not surprising

${ }^{1}$ Departments of Pediatrics, Faculty of Medicine, University of Malaya, Kuala Lumpur, Malaysia; ${ }^{2}$ Department of Obstetrics and Gynecology, Faculty of Medicine, University of Malaya, Kuala Lumpur, Malaysia; ${ }^{3}$ Department of Biomedical Science, Kulliyyah of Allied Health Sciences, International Islamic University Malaysia, Kuantan, Malaysia. Correspondence: M-K. Thong (thongmk@um.edu.my) 
because the main bulk of the consultations involved newborn infants with birth defects, children with dysmorphic features or learning disabilities, or a specific genetic condition in the community such as $\beta$-thalassemia major. ${ }^{2,3}$

Developing countries possess many unique risk factors for birth defects, e.g., cultural beliefs and taboos, poor social status of women, inadequate health budget or prioritization toward communicable diseases, and religious factors. ${ }^{5,6}$ In addition, higher rate of birth defects in these countries are often associated with low education level among women; late or absent antenatal care, which might cause missed diagnosis of preexisting medical condition or teratogenic exposure; and absence of prepregnancy planning. Due to gender inequalities, women in poor populations often discover themselves even further disadvantaged within the deprived population, as a result of being the poorest among the poor and the least educated within the insufficiently educated. In many developing countries, uneducated women delivered at home three times more (97\%) than their higher educated peers $(33 \%){ }^{7}$ Studies have consistently shown that women's educational attainment, social status, household wealth, and decisionmaking power are associated with care-seeking behaviors for maternal health services and maternal survival. ${ }^{8,9}$ Illiteracy prevents awareness of life-threatening obstetrical complications, which in turn reduces women's recognition of the need to seek risk-appropriate health care. Women's limited decision-making power, as well as constrained economic resources, likewise can inhibit their ability to seek health services and/or contribute to delays in accessing and receiving medical care even in places where services are readily available. $^{10}$

It is also not uncommon that women in developing countries receive care from traditional medical practitioners. Traditional medications or "supplements" might lead to higher rate of teratogenic exposure due to lack of understanding and supervision from professional bodies or government health agencies. According to a study on drug utilization pattern during pregnancy, mistimed pregnancies leading to exposures to radiation and category $\mathrm{X}$ drugs occur in $4 \%$ and $5.71 \%$ of pregnant females, respectively, during the first trimester. ${ }^{11}$

High rates of birth defects can be due to absence of prepregnancy planning as well. $\beta$-thalassemia major is particularly common in the Mediterranean, the Middle East, and Asia. Carrier frequencies for various genetic disorders are high in developing countries. Carrier frequencies for sickle cell hemoglobin range from 17 to $30 \%$ or more in the Indian population. $\mathrm{Hb} \mathrm{E}$ is found in the eastern half of the Indian subcontinent, and throughout Southeast Asia, where in some areas, carrier rates may exceed $60 \%$ of the population. ${ }^{12}$ Consequently, prevention programs based on carrier screening and DNA-based prenatal diagnosis are being established in a growing number of lower-resource countries. Methods to estimate access to care and the effect of interventions on the outcomes of congenital disorders are also used in developing countries. ${ }^{13,14}$ In cases of known carrier, genetic counseling is necessary to help people make informed choices. However, due to lack of nondirective genetic counseling services, many health services adopted a paternalistic approach to reproductive options and this had led to adverse outcomes before corrective measures were undertaken. ${ }^{15}$

Another cost-effective prepregnancy strategy to reduce birth defects, such as neural tube defect (NTD), in lowerresource communities is not available in a number of developing countries. ${ }^{16}$ Hence the maximum effect is precluded by lack of knowledge, cost of vitamin supplements, and the fact that the majority of pregnancies are unplanned. ${ }^{13}$ Folic acid fortification of essential foodstuffs is extremely cheap, has a negligible effect on food price, is feasible in countries at all levels of development, and enables the whole society to benefit. However, many countries in the AsiaPacific region do not have mandatory fortification of wheat flour with folic acid. ${ }^{17}$ A systematic review clearly demonstrated that fortification of flour with folic acid has had a major impact on NTD in all countries, including developing countries, where this has been reported. ${ }^{18}$

Consanguinity is still widely practiced in some developing countries. ${ }^{19}$ It was noted that the risk of birth defect is increased in consanguineous unions. ${ }^{20}$ In many Middle East and Indian subcontinent cultures, these consanguineous marriages are favored and consanguinity was significantly higher among the daughters than the parents. ${ }^{21}$ Lack of knowledge of the effect of consanguinity remains one of the main reasons that consanguinity is still practiced. ${ }^{22}$ Thus, the development of genetic counseling is extremely important in educating the couple regarding the risk and possible consequences of consanguinity. The development of genetic services allows carrier status, especially in cases of consanguinity, to be tested. With the availability of genetic counseling, the couple who both tested positive is able to reconsider whether they want to go through with the marital union.

\section{Gender selection and imbalance}

One of the most pressing issues is the abuse of genetic technology for sex selection especially in countries with strong male preference. The recognition that many girls are "missing" in countries such as China and India as a result of infanticide, abortion, and efforts to achieve preconception sex selection is longstanding. ${ }^{23,24}$

In China, the sex ratio at birth (SRB) has been steadily increasing during the past 30 years to a high of more than 130 in parts of the country. India is close behind with SRBs of up to 125 in certain states. The practice of sex selection abortion is rampant in China and India and has led to an estimated 61 to 80 million "missing" females. ${ }^{25}$ This led to the consequences of men unable to find wives. ${ }^{26}$ Besides, the paucity of females is causing the emergence of case reports from India of women forced to bear children for entire families of brothers. $^{27}$

It was suggested that "the existence of the technology and the way it is portrayed creates the perception that it is a 
necessary part of prenatal care, not merely an optional one." 28 With the increasing accessibility of genetic services with lower cost in developing countries, the mother might feel obliged to take the test. The autonomy of the women might be further limited with the information gathered with such technology as they might be pressured by their families into certain decisions such as abortion. Moreover, the responsibility for the decision is weighted upon the prospective mother as well. $^{29}$ An overwhelming majority of countries regulate prenatal diagnosis to prohibit its use for sex selection for social reasons. Professional societies and international policy documents have also joined the opposition to this practice on similar grounds. ${ }^{30}$

On the surface, it seems that the availability of genetic services has led to the abuse of sex selection and many have called for a ban on the use of genetic technology for sex selection. However, merely enforcing laws that disallowed sex determination, without addressing the sources of oppression, will merely shift the challenge to more cases of infanticide, or a slow painful death by longer-term neglect and withholding of resources for the female child. Besides, it could also turn sex determination and sex-selective abortion incognito, with illegal imaging and abortion providers serving a population favoring such services. ${ }^{31}$ In certain cultures, females do not have the right to inherit family land or wealth from their parents and many are not regarded as equal to their male counterparts in the workplace or society at large. ${ }^{32}$ From a purely cost-benefit viewpoint, a female child is indeed a substantial burden. Thus, gender selection has remained a convenient way out of the binds of this cultural conundrum in some developing countries. ${ }^{33}$

In 2000, China launched a nationwide campaign called Care for Girls to promote equality between men and women. ${ }^{34}$ Provinces throughout China have carried out public consultations and invested in strategies to reduce son preference. Recently China removed the One Child Policy, allowing families to have a second child. ${ }^{35}$ South Korea is the only country to date that has effectively reduced rising sex ratios and their success derived from wide-reaching social policy initiatives. In the mid-1990s, the government implemented prohibitions on sex determination and sex-selective abortion with legislation enforcement whereby doctors were delicensed for conducting sex-selective abortions, resulting in a significant deterrent effect. ${ }^{36}$ Widespread and influential media campaigns were initiated, encouraging couples to change their attitudes to sex-selective abortion and warning of the anticipated shortage of brides. Finally specific policies were implemented to improve the status of women by increasing their education and employment opportunities. By 2003, the sex ratio of third and fourth children had dropped to 1.5 boys per girl. ${ }^{37}$

To deal with the issue of sex-selective abortion, it is important to deal with the root cause, which is the low socioeconomic status of women in developing countries, by empowering women. In rural Bangladesh, Grameen Bank provided credit to the poorest of the poor. Accordingly, $97 \%$ of the borrowers were women who used the credit to fight poverty, while others have disputed that microcredit evangelism work. ${ }^{38}$ Studies have shown that women's educational achievement, socioeconomic status, household economic status, and decision-making ability are linked with careseeking behavior for maternal health care and thus a reduction in maternal mortality. ${ }^{32,39}$

Undoubtedly, the economic empowerment of women will ease the path to achieving gender equality, eliminate poverty, and achieve access to health care as mentioned in the Millennium Development Goals. ${ }^{40}$ A study showed that child health, which has shown improvement in the past 13 years in developing nations in terms of improvement in nutrition and reduction in mortality, is associated with improving status of women. These results imply that further advancement of women's position in society would be beneficial not just in dealing with sex-selective abortion but also children's health. ${ }^{41}$ Hence genetic technology and genetic services in these settings should be harnessed to empower women in making choices strictly for diagnostic indications for inherited conditions and not for gender selection.

\section{Lack of preventive and care services for genetic conditions and birth defects}

In LMICs, a critical shortage of health-care workers such as geneticists and surgeons is clearly evident due to the movement of skilled labor to developed countries. In addition to the chronic shortages in acute care, the more pressing need for treatment and care as well as rehabilitation and education of the children with various disabilities as a result of genetic conditions are lacking. Parents of children with developmental disabilities face many problems in getting rehabilitative services. They travel long distances, face hardships in carrying their child, and lose their day's earnings, apart from spending time and money for their child's therapy. ${ }^{42}$

According to a World Health Organization (WHO) report $70 \%$ of birth defects are preventable if evidence-based community genetics services are used. These communitybased genetics services included a number of activities for the care and prevention of genetic diseases at the community level. ${ }^{12,14}$ A good example of a cost-effective community genetic services program would be to implement expanded newborn screening (NBS) programs using dried blood spots from heel pricks and harnessing tandem mass spectrometry and genomic sequencing technology, making it possible to screen for and diagnose many inherited conditions that predispose the infant to intellectual disabilities. However, in LMICs, either the screening tool is insufficient or older technology such as cord blood screening is used or the NBS is not linked to other healthcare services, therefore, limiting the advantage of screening. ${ }^{42}$ NBS using pulse oximetry for critical congenital heart disease has been noted to be cost-effective as well but the equipment required to do this screening is not universally available in emerging countries. ${ }^{43}$ 


\section{Issues of medical technology, research, and ethics in developing countries}

Advanced reproductive technology such as preimplantation genetic screening, in vitro fertilization, and noninvasive prenatal screening (NIPS) are emerging in some of the developing countries. NIPS is easy, safe, and can be performed early in pregnancy. ${ }^{44}$ NIPS allows a wider coverage of disease screening. However, findings of unclear significance, which are always present in complex testing, could lead to an "information overload" and subsequently impair the decisionmaking process of the parents. ${ }^{45}$ Unclear findings or incidental findings might also lead to extensive diagnostic follow-up. The unclear findings of the fetus can also lead to confusion and unnecessary anxiety for parents, which is likely to persist throughout the pregnancy. ${ }^{46}$

Medical research on the problems primarily affecting the world's poorest people is lacking. ${ }^{47}$ This is due to lack of awareness for the need for genomic research; lack of funding for research, especially research regarding genetic development; and lack of qualified ethics committee members to overseer the research being conducted. ${ }^{48}$ There are ethical issues raised while conducting genomic research in the lower income countries regarding informed consent, subject's best interest, and the availability of intervention for results generated by research. ${ }^{47,49}$ A collaborative partnership between researchers and sponsors in developed countries and researchers, policy makers, and communities in developing countries helps to minimize the possibility of exploitation by ensuring that a developing country determines for itself whether the research is acceptable and responsive to the community's health problems. ${ }^{50}$ The success of efforts to build capacity in developing countries will ultimately depend on political will and credibility, adequate financing, and a responsive capacity-building plan that is based on a thorough situational analysis of the resources needed for health research and the inequities and gaps in health care. ${ }^{51}$

Another recent ethical issue is the advances in genome editing technology. ${ }^{52}$ There are concerns regarding certain developing countries that possess the genomic technology but lack the oversight of a credible ethics committee and a strong public abhorrence to the abuse of the technology. Among Western governments, there has been a longstanding consensus that manipulating the human germline is a line that should not be crossed. Some European countries have outlawed genetic modification of embryos. ${ }^{53}$ However, the United States had recently changed its legislation regarding genetic engineering, which allowed human embryo gene editing for research on cures for genetic diseases. ${ }^{54}$ A group of scientists from China had become the pioneer on human embryo genetic editing, albeit with considerable controversies. $^{55,56}$ Since then, many countries including the United States have begun research on germline editing. It is possible there may be a sea change in the level of acceptance regarding human gene modification over the next few years particularly from developing countries. It is crucial to have strict guidelines and regulations regarding human gene editing to prevent the development of human gene editing for nontherapeutic use. Strict legislation and its enforcement, as well as the presence of ethics committees, are important for the advancing of genetic technology in developing countries. ${ }^{57}$

\section{Genetics and Islam in developing countries}

It is well recognized the Islamic law is derived from (1) the Holy Quran, (2) the recorded authentic sayings and precedents set by the Prophet Muhammad, whether in word or deed (Sunnah) and the prophetic decrees; the compilation or the records of the Sunnah called Hadith, and (3) ijtihäd. Ijtihād can be defined as rulings deduced from Islamic principles based on the Holy Quran and the Hadiths by learned scholars to arrive at religious edicts (fatwas) to address a particular situation. ${ }^{58,59}$ These rulings are placed in decreasing order of authenticity and reliability respectively. This is because of the fact that the Sunnah are recorded or quoted as Hadiths by different individuals consequently subject to alterations, even distortions, and therefore the authenticity of some Hadiths is suspect because they could be modified, unless they are proven to be authentic by a majority of scholars. This uncertainty often clouds decision-making in some matters. ${ }^{58}$

The populations of a number of developing nations and emerging economies of the world are of the Islamic faith. ${ }^{59}$ The utilization of present-day health-care genetic technologies is often erroneously considered a taboo by the less enlightened members of the faith, which could render communities and individuals with no option but to accept his/her or their offspring's condition as "fated." Such situations leave no option for the alleviation of specific medical conditions. For instance, to this day there is no universally applicable religious edict (fatwa) for the termination of anomalous fetuses that are incompatible with life if its detection was inadvertently delayed beyond the limit of 120 days postfertilization. Abortion is permissible if such anomalies are detected prior to 120 days postfertilization (makruh). In such instances, adherence to assumed taboos could result in disastrous consequences for the affected individual or immediate family members, and enormous loss of taxpayer revenue. ${ }^{58}$ Adherents of Islam believe their religion is a tolerant one but its statutes have been unintentionally misrepresented by the less informed or subjected to misguidance by self-appointed custodians of the religion who are less informed themselves (which is prohibited; Holy Quran, 17:36) to a level that the faith appears intolerant and backward in character. Misguidance is abhorred in Islam (Muslim, 1631). The Holy Quran implores Muslims to learn and research the scientific facts and to become aware of what is around them (Holy Quran, 88:17-21) and praises those who have acquired knowledge (Holy Quran 39:9). Indeed the Holy Quran is replete with verses that exalt knowledge and knowledgeseeking. It is a prophetic decree that the faithful seek knowledge (al-Bukhaari, Kitaab al-'Ilm,). Enlightened adherents of Islam would concur that knowledge comes from the almighty and that such knowledge could be put to good use 
for the common good of humankind, such that harm and misery is allayed.

In all Abrahamic religions and in other religions, the question of the soul is paramount. A living individual not only has a physical body but also a soul. Therefore it follows that an embryo is not an individual unless it has a soul. This, in Islam, is generally believed to take place at about 120 days after fertilization although some schools of thought argue that life begins the moment the sperm fertilizes the egg. On the basis of Hadith Muslims assume the former to be correct. ${ }^{60-62}$

An embryo becomes an individual with the full rights of a living person only after it is bestowed a soul prior to which it is just an entity, soulless, and hence lifeless, as it were, to most Islamic scholars, and is therefore with limited rights, but not devoid of rights. In consideration of these points, the general belief in Islam is that the embryo begins life following ensoulment at day 120 after fertilization. ${ }^{60,61}$ Detailed description concerning embryo and fetal development in the Holy Quran appears to have some parallel with current scientific knowledge. ${ }^{62}$ Based on these arguments coupled with the fact that preimplantation genetic screening (PGS) does not cause destruction to the embryo or harm to any individual makes it a technology that can be permissible in Islam provided this technology is not used for sex selection or surrogacy for cosmetic reasons. PGS can be performed using next-generation sequencing (NGS) or an array-based method. This makes PGS permissible and thus acceptable in almost all countries with predominantly Muslim populations, including the Kingdom of Saudi Arabia and Iran, which are the bastions of the Sunni and Shi'ite sects of Islam.

Sunni Muslims belong to one of the four major schools of thought, which are called Madhhabs, i.e., Hanafi, Shafi'i, Maliki, and Hanbali. Madhhabs are neither clans nor sects but only schools of thought. These four schools of Sunni thought derive their Islamic rules from the Holy Quran, Hadith, and new rules based on Ijtihäd. While generally abortion is forbidden at any stage of pregnancy on the basis of two verses from the Holy Quran the application of knowledge, in this case, the use of PGS, to prevent harm to children or avoid difficulty for their parents appears permissible. The first verse states that no soul shall be killed except for judicial reasons. ${ }^{63}$ While the other verse states that killing children for fear of want, social or economic reasons, is a major $\sin ^{58,64}$ In PGS the embryos are not subjected to destruction during the procedure but genetically abnormal embryos are disposed usually in a humane manner. This could be construed as a means for avoiding harm and misery for the parents and kin.

Only a few countries apply Islamic principles as the basis of governing laws (i.e., Saudi Arabia and Iran). In these two countries the religious edicts issued by an authorized council will be considered law. In the remaining countries where even if Islam is the official religion, the laws are made by parliament or the royal court, which may or may not conform to religious edicts, but usually does. Religious edicts issued by an Islamic council of scholars in individual Islamic countries are applied but such edicts are not law until passed by their parliament or equivalent authority.

Past and contemporary Islamic scholars have opined that abortion is totally forbidden at any stage of pregnancy. However, some scholars consider it permissible during the first 40 days of pregnancy at a stage of pregnancy called the nutfah, but forbidden thereafter. Others consider abortion permissible during the first 80 days of pregnancy at a stage of pregnancy referred to as the alaqah but forbidden thereafter. While others consider it permissible during the stages of pregnancy in the first 4 months provided there are reasonable grounds for abortion. ${ }^{58}$ Based on these schools of thought, it appears reasonable to assume the disposal of PGS-determined abnormal preembryos between days 3 and 7 postfertlization is permissible.

Iran, on the other hand, has never actually enacted a "gender selection act" as such, and at the same time, it has never issued a ban on it either. As a result, clinics and hospitals offer PGD for social as well as disease avoidance reasons. The International Islamic Fiqh Council (IIFC) is an Islamic Sunni institution of the World Muslim League based in Mecca, Saudi Arabia. Its members are representatives of individual countries where Islam is the predominant religion. They are chosen by their governments as the senior-most Islamic clerics/scholars of their respective countries. Their main task is to meet on a regular basis to discuss current debatable issues affecting Muslims and to formulate rulings for resolving such issues.

The latest regulations issued by the IIFC state that if it was proven before the passage of 120 days of pregnancy by a committee of at least two competent and trustworthy medical experts and confirmation based on examination with the use of appropriate equipment and laboratory findings that the fetus is unwell with serious anomalies, it is permissible to abort following the request of the parents. On the basis of this ruling, the application of PGS to identify and dispose of abnormal human preembryos is permissible. ${ }^{58}$ This ruling was based on a verse in the Holy Quran that indicates a mother shall not be made to suffer harm because of her child. ${ }^{65}$

The Iranian parliament amended its regulations on abortion according to the recommendations of the Guardian's Council (the principles of the Shi' ite sect) in 2005 (ref. ${ }^{66}$ ). Their ruling states that therapeutic abortions may be performed under certain conditions. First, the fetus must be less than 4 months of age, that is, before ensoulment. Second, the fetus must be suffering from profound developmental delay or profound deformations or malformations. Third, these fetal problems must be the cause of extreme suffering or hardship for the mother or the fetus. Fourth, the life of the mother should be in danger. Fifth, both the mother and the father must give their consent to the procedure. The physician performing the abortion shall not be penalized for the performance of these services. The disposal of PGS-identified abnormal 
preembryos in the Shi'ite community appears to satisfy all of the above except for rule 4 , which is indeterminate and could be construed as potentially hazardous to the mother. Of interest is the report that apparently Iran has not enacted a ban on gender selection, while at the same time has not banned it. Consequently PGS is offered for social as well as disease avoidance reasons. ${ }^{67}$

\section{Guiding principles of Islam}

Islam in general has provided broad guiding principles that can be utilized to overcome any dilemma. The first guideline asks one to consider whether a particular action fulfills the basic objectives of jurisprudence. These objectives include (1) preservation of religion, (2) preservation of life, (3) preservation of genealogy or parentage, (4) preservation of the mind and health, and (5) preservation of property. The second guideline seeks to prevent detriment, which has a priority over the fulfillment of a benefit or interest. ${ }^{60,61}$ These guiding principles and the Holy Quranic recommendations that consanguinity be avoided when put together would lead to inferences that suggest fetal anomalies have to be prevented, which again favors the argument for PGS. ${ }^{58}$

PGS is useful for couples pursuing assisted reproductive technology (ART) treatment for the alleviation of a history of childlessness or recurrent pregnancy loss. The incidence of aneuploidy in human in vitro generated embryos is very high, ranging from about $50 \%$ to as high as $80 \%$ in women in the vicinity or above 40 years of age. ${ }^{68,69}$ Selecting euploid embryos for transfer reduces miscarriage and enhances the chances of pregnancy and also promises the sibling is genetically normal. ${ }^{69-72}$ Furthermore PGS eliminates the need for invasive prenatal diagnostic tests, i.e., chorionic villus sampling (CVS) or amniocentesis, thereby preventing the need for therapeutic termination of pregnancy. Instead, it gives parents the opportunity of having their own unaffected child by selecting normal embryos by utilization of PGS for transfer during ART treatment procedures. ${ }^{73}$ The main issue confronting PGS is the need to discard genetically abnormal embryos. This matter has been discussed at length by Fadel $^{73}$ and Hug. ${ }^{66}$ According to them there is no clear-cut decision on this matter. It depends entirely on what one thinks the moral status is of an embryo.

Muslims are aware of and heed the Hadith, which states that it is incumbent upon every Muslim to seek knowledge and to seek cures for diseases because all Muslims are aware of numerous Hadiths that convey that for every disease there is a cure. In the years to come, the continuously emerging novel medical technologies at our disposal will provide enormous opportunities to help prevent serious health disabilities. Novel treatment modalities could help avoid situations that could result in lifelong disability and suffering for the affected individual, pose a serious difficulty to the immediate family members, and a burden on the health-care system. Muslims recognize that no one is required to endure either harm or difficulty due to religion as indicated in two Holy Quranic verses. ${ }^{7475}$

\section{CONCLUSION}

It is clear genetics and genomics are changing health-care services rapidly even in low and middle income countries, because the decreasing cost of genetic sequencing and rapid analysis such as NIPS have made these technologies more accessible. Hence there is a need to ensure that access and application of genomic technology is utilized appropriately and in a cost-effective manner. Many of the issues highlighted here are not unique and share similarities with both developed countries and LMIC alike.

Moving forward, birth defect registries are needed to provide accurate data to health-care planners and policy makers in the region. Capacity-building in genetic diagnostic services and genetic counseling expertise that respect the beliefs, cultures, religions, and traditions of the families are urgently needed. This includes a tremendous need to have an adequate workforce to provide reproductive services and prenatal screening for all women during their reproductive years. Public education and awareness programs supported by appropriate legislation may also be required to slowly reduce the gender imbalance in many of these countries in the AsiaPacific region.

Finally there must be ongoing discussion, communication, and collaborations with geneticists and research scientists in developed countries to share their expertise and experience so that training, development of clinical services, and research can be carried out. It is hoped that through both internal development efforts and collaborative programs all countries in the Asia-Pacific region will eventually have the necessary resources to support a clinical genetics services for all individuals living within this region.

\section{DISCLOSURE}

The authors declare no conflicts of interest.

\section{REFERENCES}

1. Laurino MY, Leppig KA, Abad PJ, et al. A report on ten Asia Pacific countries on current status and future directions of the genetic counseling profession: the establishment of the Professional Society of Genetic Counselors in Asia. J Genet Couns. 2018;27:21-32.

2. Christianson A, Howson CP, Modell B. March of Dimes: global report on birth defects. The hidden toll of dying and disabled children. White Plains, NY: March of Dimes Birth Defects Foundation; 2006. http://www. marchofdimes.org/materials/global-report-on-birth-defects-the-hiddentoll-of-dying-and-disabled-children-full-report.pdf. Accessed 10 April 2018.

3. World Health Organization. 2010 World Health Assembly report on birth defects. http://apps.who.int/gb/ebwha/pdf_files/WHA63/A63_10-en.pdf? $u a=1 \& u a=1$. Accessed 10 April 2018.

4. Thong MK. Birth defects registries in the genomics era: challenges and opportunities for developing countries. Front Pediatr. 2014;2:60.

5. World Health Organization. Congenital anomalies. Geneva, Switzerland: World Health Organization; 2015. http://www.who.int/mediacentre/ factsheets/fs370. Accessed 10 April 2018.

6. Egbe AC. Birth defects in the newborn population: race and ethnicity. Pediatr Neonatol. 2015;56:183-188.

7. Dalal K, Shabnam J, Andrews-Chavez J, et al. Economic empowerment of women and utilization of maternal delivery care in Bangladesh. Int J Prev Med. 2012;3:628.

8. Anand S, Barnighausen T. Human resources and health outcomes: cross country econometric study. Lancet. 2004;364:1603-1609. 
9. Victora CG, Wagstaff A, Schellenberg JA, et al. Applying an equity lens to child health and mortality: more of the same is not enough. Lancet. 2003;362:233-241.

10. Ahmed S, Creanga AA, Gillespie DG, Tsui AO. Economic status, education and empowerment: implications for maternal health service utilization in developing countries. PLoS One. 2010;5:e11190.

11. Weatherall DJ, Clegg JB. Inherited haemoglobin disorders: an increasing global health problem. Bull World Health Organ. 2001;79:704-712.

12. Modell B. Recommendations for introducing genetic services in developing countries. Nat Rev Genet. 2003;4:61-67.

13. Blencowe H, Moorthie S, Darlison MW, Congenital Disorders Expert Group. Methods to estimate access to care and the effect of interventions on the outcomes of congenital disorders. J Community Genet 2018 March 17; https://doi.org/10.1007/s12687-018-0359-3. [Epub ahead of print].

14. World Health Organization. Management of birth defects and haemoglobin disorders: report of a joint WHO-March of Dimes meeting. Geneva, Switzerland: WHO; 2006.

15. Weatherall DJ. The burden of genetic disease in the developing world: the example of inherited blood diseases. Genomics and Health in the Developing World. In: Kumar D (ed) 2012; 217-9. Oxford University Press, New York.

16. World Health Organization. Folic acid and the prevention of neural tube defects: from research to public health practice. Rep. WHO/EURO Meet. Reg. Policy Prev. Congenit. Disord., Rome, Italy, 11-12 Nov. Geneva: WHO. 2002

17. Kancherla V, Zimmerman S, Countries with an immediate potential for primary prevention of spina bifida and anencephaly: mandatory fortification of wheat flour with folic acid. Birth Defects Res. 2018;110:956-965.

18. Castillo-Lancellotti C, Tur JA, Uauy R. Impact of folic acid fortification of flour on neural tube defects: a systematic review. Public Health Nutr. 2013;16:901-911.

19. Bittles $A H$, Black ML. Evolution in health and medicine Sackler colloquium: consanguinity, human evolution, and complex diseases. Proc Natl Acad Sci U S A. 2010;107(suppl 1):1779-1786.

20. Sabbagh HJ, Innes NP, Sallout BI, et al. Birth prevalence of non-syndromic orofacial clefts in Saudi Arabia and the effects of parental consanguinity. Saudi Med J. 2015;36:1076-1083.

21. Alharbi OA, Al-Shaia WA, Al-Hamam AA, et al. Attitude of Saudi Arabian adults towards consanguineous marriage. Qatar Med J. 2015;2015:12.

22. Warsy AS, Al-Jaser MH, Albdass A, et al. Is consanguinity prevalence decreasing in Saudis? A study in two generations. Afr Health Sci. 2014;14:314-321.

23. Jha $P$, Kumar $R$, Vasa $P$, et al. Low male to-female sex ratio of children born in India: national survey of 1.1 million households. Lancet. 2006;367:211-218.

24. Zhu WX, Lu L, Hesketh T. China's excess males, sex selective abortion, and one child policy: analysis of data from 2005 national intercensus survey. BMJ. 2009;338:b1211.

25. Sen A. Missing women-revisited. BMJ. 2003;327:1297-1298.

26. Hesketh $T$, Lu L, Xing ZW. The consequences of son preference and sex selective abortion in China and other Asian countries. CMAJ. 2011;183:1374-1377

27. Lobo R, Genuis G. Socially repugnant or the standard of care. Can Fam Physician. 2014;60:212-216.

28. Seavilleklein V. Challenging the rhetoric of choice in prenatal screening. Bioethics. 2009;23:68-77.

29. Garcia E, Timmermans DR, van Leeuwen E. Rethinking autonomy in the context of prenatal screening decision-making. Prenat Diagn. 2008;28: $115-120$.

30. A Joint statement from the International Confederation of Midwives (ICM) and the International Federation of Gynecology and Obstetrics (FIGO). Non-medical gender-biased sex selection. 2017. https://www. figo.org/news/non-medical-gender-biased-sex-selection-joint-icm-figostatement-0015659. Accessed 8 April 2018.

31. Zilberberg J. Sex selection and restricting abortion and sex determination. Bioethics. 2007;21:517-519.

32. Singh $M$, Health and welfare of women and child survival: a key to nation building. Indian J Pediatr. 2018;85:523-527.

33. Nie JB. Non-medical sex-selective abortion in China: ethical and public policy issues in the context of 40 million missing females. $\mathrm{Br}$ Med Bull. 2011;98:7-20.
34. Li S, Shang Z, Feldman MW. Social management of gender imbalance in China: a holistic governance framework. Econ Polit Wkly. 2013;48: 79-86.

35. Gu C, Zhu X, Ding Y, et al. A qualitative study of nulliparous women's decision making on mode of delivery under China's two-child policy. Midwifery. 2018;62:6-13.

36. Park $\mathrm{CB}, \mathrm{Cho} \mathrm{NH}$. Consequences of son preference in a low-fertility society: imbalance of the sex ratio at birth in Korea. Popul Dev Rev. 1995;21:59-84.

37. Kim DS. Missing girls in South Korea: trends, levels and regional variations. Population. 2004;59:865-878.

38. Bond P. The meaning of the 2006 Nobel Peace Prize. Microcredit evangelism, health, and social policy. Int J Health Serv. 2007;37:229-249.

39. Al RA, Afifi M, Mabry RM. Women's autonomy, education and employment in Oman and their influence on contraceptive use. Reprod Health Matters. 2004;12:144-154.

40. Ongolo-Zogo P, Lavis JN, Tomson G, et al. Assessing the influence of knowledge translation platforms on health system policy processes to achieve the health millennium development goals in Cameroon and Uganda: a comparative case study. Health Policy Plan. 2018;33:539-554.

41. Heaton TB. Are improvements in child health due to increasing status of women in developing nations? Biodemography Soc Biol. 2015;61: 252-265.

42. Yousafzai AK, Lynch P, Gladstone M. Moving beyond prevalence studies: screening and interventions for children with disabilities in low-income and middle-income countries. Arch Dis Child. 2014;99:840-848.

43. Peterson C, Grosse SD, Glidewell J, et al. A public health economic assessment of hospitals' cost to screen newborns for critical congenital heart disease. Public Health Rep. 2014;129:86-93.

44. De Jong A, Dondorp WJ, de Die-Smulders CE, et al. Non-invasive prenatal testing: ethical issues explored. Eur J Hum Genet. 2010;18:272-277.

45. de Wert G, Dondorp W. Ethical issues. In: van Vugt M, Shulman K, eds. Prenatal Medicine. New York/London: Taylor \& Francis; 2006:575-604.

46. Best S, Wou K, Vora N, et al. Promises, pitfalls and practicalities of prenatal whole exome sequencing. Prenat Diagn. 2018;38:10-19.

47. De Vries J, Bull SJ, Doumbo O, et al. Ethical issues in human genomics research in developing countries. BMC Med Ethics. 2011;12:5-5.

48. Westfall JM, Zittleman L, Felzien $M$, et al. Institutional review board training when patients and community members are engaged as researchers. Fam Pract. 2017;34:301-304.

49. Emanuel EJ, Currie XE, Herman A. Undue inducement in clinical research in developing countries: is it a worry? Lancet. 2005;366:336-340.

50. Participants in the 2001 Conference on Ethical Aspects of Research in Developing Countries. Ethics: fair benefits for research in developing countries. Science. 2002;298:2133-2134.

51. Lansang MA, Dennis R. Building capacity in health research in the developing world. Bull World Health Organ. 2004;82:764-770.

52. Savulescu J, Pugh J, Douglas T, Gyngell C. The moral imperative to continue gene editing research on human embryos. Protein Cell. 2015:6:476-479.

53. Lander ES. Brave new genome. N Engl J Med. 2015;373:5-8.

54. Church G. Compelling reasons for repairing human germlines. N Engl J Med. 2017;77:1909-1911.

55. Liang $P, X u Y$, Zhang $X$, et al. CRISPR/Cas9-mediated gene editing in human tripronuclear zygotes. Protein Cell. 2015;6:363-372.

56. Liang $P$, Ding $C$, Sun $H$, et al. Correction of $\beta$-thalassemia mutant by base editor in human embryos. Protein Cell. 2017;8:811-822.

57. Cwik B. Designing ethical trials of germline gene editing. N Engl J Med. 2017;377:1911-1913.

58. Al-Matary A, Ali J. Controversies and considerations regarding termination of pregnancy for fetal anomalies in Islam. BMC Med Ethics. 2014;15:10.

59. Al-Aqeel Al. Islamic ethical framework for research into and prevention of genetic diseases. Nat Genet. 2007;39:1293-1298.

60. Gatrad AR, Sheikh A. Medical ethics and Islam: principles and practice. Arch Dis Child. 2001;84:72-75.

61. Hedayat KM, Shooshtarizadeh P, Raza M. Therapeutic abortion in Islam: contemporary views of Muslim Shiite clerics and effect of recent Iranian legislation. J Med Ethics. 2006;32:652-657.

62. Moore KL. A scientist's interpretation of references to embryology in the Holy Quran. J Islam Med Assoc North Am. 1986;18:15-17.

63. Hessini. L. Abortion and Islam: policies and practice in the Middle East and North Africa. Reprod Health Matters. 2007;15:75-84. 
64. DeJong J, Jawad R, Mortagy I, Shepard B. The sexual and reproductive health of young people in the Arab countries and Iran. Reprod Health Matters. 2005;13:49-59.

65. The Holy Quran, Al-Baqara 2:286

66. Hug K. Therapeutic perspectives of human embryonic stem cell research versus the moral status of a human embryo-does one have to be compromised for the other? Medicina (Kaunas). 2006;42:107-114.

67. Karoubi E. Choosing gender in Iran. Souciant. 20 January 2015. http:// souciant.com/2015/01/choosing-gender-in-iran. Accessed 10 January 2018.

68. Harton GL, Munne S, Surrey M, et al. Diminished effect of maternal age on implantation after preimplantation genetic diagnosis with array comparative genomic hybridization. Fertil Steril. 2013;100:1695-1703.

69. Yang Z, Liu J, Collins GS, et al. Selection of single blastocysts for fresh transfer via standard morphology assessment alone and with array CGH for good prognosis patients: results from a randomised pilot study. $\mathrm{Mol}$ Cytogenet. 2012;5:24.
70. Forman EJ, Hong $\mathrm{KH}$, Ferry $\mathrm{KM}$, et al. In vitro fertilization with single euploid blastocyst transfer: a randomized controlled trial. Fertil Steril. 2013;100:100-107.

71. Grifo JA, Hodes-Wertz B, Lee HL, et al. Single thawed euploid embryo transfer improves IVF pregnancy, miscarriage, and multiple gestation outcomes and has similar implantation rates as egg donation. J Assist Reprod Genet. 2013;30:259-264.

72. Fadel HE. Preimplantation genetic diagnosis: rationale and ethics, an Islamic perspective. J Islam Med Assoc North Am. 2007;39: 150-157.

73. Olesen A, Nor SN, Amin L. Religious scholars' attitudes and views on ethical issues pertaining to pre-implantation genetic diagnosis (PGD) in Malaysia. J Bioeth Inq. 2016;13:419-429. https://doi.org/10.1007/ s11673-016-9724-2

74. The Holy Quran, Al-Baqara 1:78.

75. The Holy Quran, Al-Hajj 22:78. 